\title{
HUBUNGAN SARANA SANITASI DENGAN KEJADIAN DIARE PADA BALITA DI KELURAHAN WAY LAGA KECAMATAN SUKABUMI KOTA BANDAR LAMPUNG TAHUN 2017
}

\author{
Fadila Dwi Anjani ${ }^{1)}$
}

\begin{abstract}
Abstrak
Diare merupakan penyakit yang lebih dominan menyerang balita karena daya tahan tubuhnya yang masih lemah. Faktor lingkungan yang buruk dapat menyebabkan seorang balita terkena diare. Penelitian dilakukan di Kelurahan Way Laga Kecamatan Sukabumi Kota Bandar Lampung mulai bulan Mei sampai Juni 2017, menggunakan rancangan kasus-kontrol (casus control) terhadap 42 responden ibu balita diare (kasus) dan responden ibu balita tidak diare dengan jumlah 42 (kontrol).

Survei dilakukan terhadap responden meliputi jamban, penyediaan air bersih, tempat pembuangan sampah, dan saluran pembuangan air limbah. Dari empat variabel yang di uji, hanya 2 variabel yang memiliki hubungan secara bermakna dengan kejadian diare pada balita yaitu sarana sanitasi (penyediaan air bersih dan saluran pembuangan air limbah). Lebih lanjut, hasil analisis menunjukkan bahwa sarana sanitasi yang berhubungan dengan kejadian diare pada balita adalah sarana penyediaan air bersih $(p=0,000)(O R=30,4)$, dan saluran pembuangan air limbah $(p=0,000)$ $(\mathrm{OR}=23,68)$.

Puskesmas Way Laga disarankan untuk mengurangi risiko tersebut perlu upaya yang dilakukan melalui perbaikan sarana penyediaan air bersih seperti perlindungan terhadap pencemaran sekitar sumber, perbaikan dan pemeliharaan jamban, perbaikan SPAL, serta penyuluhan kesehatan lingkungan berkaitan dengan penyakit berbasis lingkungan.
\end{abstract}

Kata Kunci: Diare, Balita, Sarana Sanitasi.

1)Alumni Program Studi D4 Kesehatan Lingkungan Poltekkes Tanjungkarang

\section{PENDAHULUAN}

Sanitasi merupakan salah satu tantangan yang paling utama bagi negara-negara berkembang karena menurut World Health Organization (WHO), penyakit diare membunuh satu anak di dunia ini setiap 15 detik, karena akses sanitasi masih terlalu rendah. Hal ini menimbulkan masalah kesehatan lingkungan yang besar, serta merugikan pertumbuhan ekonomi dan potensi sumber daya manusia pada skala Nasional (Azwar, 2009).

Diare merupakan penyakit berbasis lingkungan dan terjadi hampir di seluruh daerah geografis di dunia. Menurut data World Health Organization (WHO) pada tahun 2013, setiap tahunnya ada sekitar 1,7 milyar kasus diare dengan angka kematian 760.000 anak di bawah 5 tahun. Pada Negara berkembang, anak-anak dibawah usia 3 tahun rata-rata mengalami 3 episode diare pertahun. Setiap episodenya, diare akan menyebabkan kehilangan nutrisi yang dibutuhkan anak untuk tumbuh, sehingga diare merupakan penyebab utama malnutrisi pada anak dan menjadi penyebab kematian kedua pada anak berusia dibawah 5 tahun.

Beberapa faktor yang berkaitan dengan kejadian diare yaitu penyediaan air bersih, pembuangan kotoran (jamban), tempat pembuangan sampah, dan saluran pembuangan air limbah (Notoatmodjo, 2007). Banyak faktor yang secara langsung maupun tidak langsung menjadi pendorong terjadinya diare yaitu faktor agent, penjamu, lingkungan dan perilaku. Faktor lingkungan merupakan faktor yang paling dominan yaitu penyediaan air bersih dan pembuangan tinja, kedua faktor berinteraksi bersama dengan perilaku manusia. Apabila faktor lingkungan tidak sehat karena tercemar kuman diare serta terakumulasi dengan perilaku manusia yang tidak sehat, maka penularan diare dengan mudah dapat terjadi (Zubir, 2006).

Sampai saat ini kejadian diare masih merupakan masalah kesehatan masyarakat di 
Kota Bandar Lampung. Walaupun secara umum angka kesakitan masih berfluktuasi, dan juga dilaporkan oleh sarana pelayanan dan kader kesehatan diare ini masih sering menimbulkan Kejadian Luar Biasa (KLB) yang cukup banyak bahkan menimbulkan kematian.

\section{METODE}

Penelitian menggunakan rancangan Case Control dengan pendekatan retrospektif dimana efek diidentifikasikan pada saat ini kemuadian faktor risiko diidentifikasi terjadinya pada waktu yang lalu (Notoatmodjo, 2002).

Dalam penelitian ini peneliti ingin membandingkan kelompok yang menderita diare (kasus) dan kelompok yang tidak menderita diare (kontrol). Berdasarkan kejadian diare pada balita di Kelurahan Way Laga Kecamatan Sukabumi Kota Bandar Lampung, dengan variabel pada saat analisis yaitu jamban, penyediaan air bersih, tempat pembuangan sampah, dan saluran pembuangan air limbah.

Subjek penelitian ini adalah ibu yang memiliki balita di Kelurahan Way Laga Kecamatan Sukabumi Kota Bandar Lampung. a. Kriteria Inklusi

Kriteria inklusi adalah karakteristik umum dari subjek penelitian yang layak untuk dilakukan penelitian atau dijadikan responden. Kriteria inklusi pada penelitian ini adalah :
- Ibu yang pernah membawa balita berobat di Puskesmas Way Laga Kelurahan Way Laga Kecamatan Sukabumi Kota Bandar Lampung.

- Ibu yang memiliki balita yang bertempat tinggal di Kelurahan Way Laga Kecamatan Sukabumi Koia Bandar Lampung.

- Merupakan warga yang berdomisili (tinggal menetap) dan memiliki rumah di Kelurahan Way Laga Kecamatan Sukabumi Kota Bandar Lampung.

- Bersedia menjadi responden.

\section{b. Kriteria Eksklusi}

Kriteria eksklusi adalah karakteristik umum dari subjek penelitian yang tidak layak dijadikan sebagai responden. Kriteria eksklusi pada penelitian ini adalah:

- Ibu yang tidak memiliki balita yang bertempat tinggal di Kelurahan Way Laga Kecamatan Sukabumi Kota Bandar Lampung.

- Satu rumah yang terdapat lebih dari satu keluarga yang memiliki balita yang menderita diare.

- Bukan merupakan warga yang berdomisili (tinggal menetap) dan memiliki rumah di Kelurahan Way Laga Kecamatan Sukabumi Kota Bandar Lampung.

- Tidak bersedia menjadi responden

Besar sampel dalam penelitian ini di tentukan dengan menggunakan rumus yang dikemukakan oleh Ariawan (1998:37) untuk uji hipotesis Odds Ratio (OR) dengan formula :

$$
\mathrm{P} 1=\frac{(\mathrm{OR}) \mathrm{P} 2}{(\mathrm{OR}) \mathrm{P} 2+(1-\mathrm{P} 2)}
$$

Untuk mencari n digunakan rumus sebagai berikut :

$$
\mathrm{n}=\frac{\left[Z 1-\frac{\alpha}{2} \sqrt{2 P(1-P)}+Z 1-\beta \sqrt{P 1(1-P 1)}+P 2(1-P 2)\right]^{z}}{(P 1-P 2)^{2}}
$$

Keterangan :

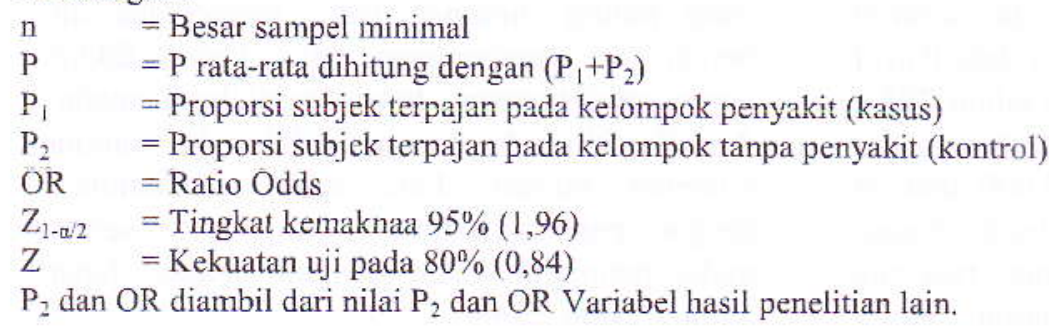


Tabel 1. Hasil Perhitungan Besar Sampel Minimal

\begin{tabular}{llcccc}
\hline No & \multicolumn{1}{c}{ Variabel } & $\mathbf{P}_{2}$ & OR & $\mathbf{n}$ & Peneliti (tahun) \\
\hline 1. & Penyediaan Air Bersih & 0,294 & 2,92 & 15 & Bintaro, 2010 \\
2. & Jamban & 0,235 & 3,66 & 42 & Bintaro, 2010 \\
3. & TPS Sementara & 0,13 & 3,82 & 39 & Rizkyanto, 2014 \\
4. & Saluran Pembuangan Air Limbah & 0,27 & 3,72 & 34 & Rizkyanto, 2014 \\
\hline
\end{tabular}

Berdasarkan hasil perhitungan menggunakan rumus uji hipotesis odds ratio, maka sampel yang diperlukan dalam penelitian ini sebanyak 42 sampel kasus dan 42 sampel kontrol. Dalam penelitian ini yang dipilih adalah kasus dan kontrol tidak berpadanan.

\section{HASIL}

Pada Tabel 2 terlihat bahwa frekuensi kejadian diare pada sarana penyediaan air bersih yang tidak memenuhi syarat sebanyak $76,2 \%$, dan pada sarana penyediaan air yang memenuhi syarat sebanyak $23,8 \%$. Sedangkan yang tidak terkena diare dengan sarana penyediaan air bersih yang memenuhi syarat sebanyak $9,5 \%$, dan pada sarana penyediaan air bersih yang memenuhi syarat sebanyak $90,5 \%$.

Hasil uji Chi Square diperoleh nilai $\mathrm{p}=$ 0,000 dimana $\mathrm{p} \leq 0,05$ dengan $\mathrm{OR}=30,4$. Hal ini menunjukkan bahwa sarana penyediaan air bersih yang tidak memenuhi syarat akan menyebabkan kejadian diare sebesar 30,4 kali dibandingkan dengan sarana penyediaan air bersih yang memenuhi syarat.

Tabel 2. Hubungan Penyediaan Air Bersih dengan Kejadian Diare

\begin{tabular}{lccccccc}
\hline \multirow{2}{*}{ Penyediaan Air Bersih } & \multicolumn{4}{c}{ Kejadian Diare } & \multirow{2}{*}{ P } & OR \\
\cline { 2 - 5 } & \multicolumn{3}{c}{ Diare } & \multicolumn{2}{c}{ Tidak Diare } & Value & \\
\cline { 2 - 4 } & $\mathrm{n}$ & $\%$ & $\mathrm{~N}$ & $\%$ & & \\
\hline Tidak Memenuhi Syarat & 32 & 76,2 & 4 & 9,5 & & 30,4 \\
Memenuhi Syarat & 10 & 23,8 & 38 & 90,5 & 0,000 & $(8,64-106,24)$ \\
Total & 42 & 100 & 42 & 100 & & \\
\hline
\end{tabular}

Tabel 3 menggambarkan, pada kelompok responden yang menderita diare memiliki tempat pembuangan sampah dan memenuhi syarat sebanyak $64,3 \%$, dan responden yang tidak memiliki tempat pembuangan sampah serta tidak memenuhi syarat sebanyak $35,7 \%$. Sedangkan pada kelompok responden tidak diare yang memiliki tempat pembuangan sampah sementara yang tersedia dan memenuhi syarat sebanyak $78,6 \%$, dan tidak memenuhi syarat sehanyak $21,4 \%$.

Berdasarkan uji Chi Square diperoleh nilai $\mathrm{p}=0,227$ sehingga tidak ada hubungan antara tempat pembuangan sampah sementara dengan kejadian diare.

Tabel 3. Hubungan Tempat Pembuangan Sampah dengan Kejadian Diare

\begin{tabular}{|c|c|c|c|c|c|}
\hline \multirow{3}{*}{$\begin{array}{c}\text { Tempat Pembuangan } \\
\text { Sampah }\end{array}$} & \multicolumn{4}{|c|}{ Kejadian Diare } & \multirow{3}{*}{$p$ value } \\
\hline & \multicolumn{2}{|c|}{ Diare } & \multicolumn{2}{|c|}{ Tidak Diare } & \\
\hline & $\mathrm{n}$ & $\%$ & $\mathrm{~N}$ & $\%$ & \\
\hline Tidak Memiliki & 15 & 35,7 & 9 & 21,4 & \\
\hline Memiliki & 27 & 64,3 & 33 & 78,6 & 0,227 \\
\hline Total & 42 & 100 & 42 & 100 & \\
\hline
\end{tabular}

Proporsi dari variabel saluran pembuangan air limbah menunjukkan bahwa $56 \%$ tidak ada SPAL, dan $44 \%$ ada SPAL. Hal ini menunjukkan bahwa saluran pembuangan air limbah dalam kondisi yang buruk karena lebih banyak yang tidak ada SPAL. Secara lebih detil dapat dipaparkan bahwa frekuensi kejadian diare pada balita yang tidak ada SPAL dalam saluran pembuangan air limbah sebanyak $76,2 \%$, dan yang telah ada SPAL dalam pembuangan air limbahnya sebanyak $23,8 \%$. Sedangkan yang tidak terkena diare dengan saluran pembuangan air limbah yang tidak ada SPAL sebanyak $11,9 \%$, dan yang 
telah ada SPAL dalam saluran pembuangan air limbah sebanyak $88,1 \%$. Hasil tersebut disajikan pada tabel 4 .

Berdasarkan uji Chi Square diperoleh nilai $\mathrm{p}=0,000$, dan $\mathrm{OR}=23,68$. Hal ini menunjukkan bahwa tidak ada SPAL akan mengakibatkan kejadian diare scbesar 23,68 kali dibandingkan dengan yang ada SPAL.

Tabel 4. Hubungan Saluran Pembuangan Air Limbah dengan Kejadian Diare

\begin{tabular}{|c|c|c|c|c|c|c|}
\hline \multirow{3}{*}{$\begin{array}{c}\text { Saluran Pembuangan } \\
\text { Air Limbah }\end{array}$} & \multicolumn{4}{|c|}{ Kejadian Diare } & \multirow{3}{*}{$\begin{array}{c}\mathrm{P} \\
\text { Value }\end{array}$} & \multirow{3}{*}{$\begin{array}{c}\text { OR } \\
\text { (CI 95\%) }\end{array}$} \\
\hline & \multicolumn{2}{|c|}{ Diare } & \multicolumn{2}{|c|}{ Tidak Diare } & & \\
\hline & $\mathrm{N}$ & $\%$ & $\mathrm{n}$ & $\%$ & & \\
\hline Tidak Memiliki & 32 & 76,2 & 5 & 11,9 & & 23,68 \\
\hline Memiliki & 10 & 23,8 & 37 & 88,1 & 0,000 & $(7,326-76,538)$ \\
\hline Total & 42 & 100 & 42 & 100 & & \\
\hline
\end{tabular}

\section{PEMBAHASAN}

\section{a. Sarana Penyediaan Air Bersih}

Air salah satu jenis sumberdaya yang biasa dimanfaatkan oleh manusia dalam melakukan aktivitas mereka sehari-hari termasuk di antaranya adalah sanitasi. Pada penelitian ini melakukan observasi terhadap konstruksi sarana penyediaan air bersih seperti jarak lebih dari 10 meter dari sumber pencemar, lantai kedap air, ukuran cincin sumur 3 meter, sumur dalam keadaan tertutup, memiliki timba khsusus, dan keadaan sumur bersih (Tabel 2).

Hasil penelitian ini juga sejalan dengan Bintaro (2010) yaitu diperoleh hasil uji statistik yaitu $\mathrm{p}=0,009$ dimana $\mathrm{p} \leq 0,05$ berarti Ho ditolak, maka dapat disimpulkan ada hubungan yang bermakna antara sarana penyediaan air bersih dengan kejadian diare pada balita. Terjadinya penyebaran penyakit menular pada air dapat terjadi apabila air berperan sebagai penyebar mikroorganisme patogen, sebagai sarang serangga penyebar penyakit atau ketersediaan air bersih tidak mencukupi untuk keperluan sehari-hari sehingga masyarakat tidak dapat membersihkan dirinya sendiri dengan baik. Air juga dapat berperan sebagai sarang hospes sementara penyakit.

Tingginya nilai OR ini tidak menjadikannya faktor risiko utama untuk diintervensi, tetapi melalui pertimbangan sarana dan prasarana serta kemampuan dari masyarakat. Akibat dari kondisi sarana penyediaan air bersih yang tidak memenuhi syarat menyebabkan terjadinya penyakit diare. Sebaiknya responden lebih meningkatkan kondisi sarana penyediaan air bersih seperti jarak sumur gali lebih dari 10 meter dari sumber pencemar, lantai kedap air dengan bangunan di plester/semen minimal 1 meter dari dinding sumur, sumur tertutup agar terhindar dari vektor penyakit, memiliki timba khusus, dan keadaan sumur bersih.

\section{b. Jamban}

Jamban merupakan masalah pokok karena kotoran manusia adalah sumber penyebaran penyakit yang multikompleks. Beberapa penyakit yang dapat disebarkan oleh tinja manusia antara lain : tipus, diare, disentri, kolera, bermacam-macam cacing seperti cacing gelang, kremi, tambang, dan pita. Oleh karena itu diperlukan sarana jamban yang sehat sebagai tempat pembuangan kotoran.

Dari hasil data yang telah di analisis di Kelurahan Way Laga responden kasus dan kontrol keseluruhan sudah memiliki jamban dan sudah memenuhi syarat jamban sehat yaitu sebanyak 100\%. Hal ini menunjukkan responden telah memiliki jamban yang baik. Kelemahan penelitian pada variabel jamban ini kemungkinan sampel terlalu sedikit oleh sebab itu didapatkan hasil sebanyak $100 \%$ memenuhi syarat.

Hasil penelitian ini juga sejalan dengan Nugroho (2011) yaitu diperoleh hasil uji statistik yaitu $p=0,624$ dimana $p>0,05$ berarti Ho gagal ditolak, maka dapat disimpulkan tidak ada hubungan antara sarana jamban dengan kejadian diare pada balita.

Walaupun jamban di Kelurahan Way Laga sudah memenuhi syarat ada baiknya responden lebih meningkatkan kondisi sarana jamban seperti memperhatikan kontruksi pada ventilasi $10-15 \%$ dari luas lantai, lantai kuat dan kedap air, penampungan tinja/septictank kedap air, jarak jamban dengan sumber air $>10$ meter agar tetap menjadi jamban yang sehat. 


\section{c. Tempat Pembuangan Sampah Sementara}

Sampah adalah semua zat atau benda yang sudah tidak terpakai baik yang berasal dari rumah tangga atau hasil proses industri. Jenisjenis sampah antara lain, yakni sampah anorganik dan organik. Biasanya sampah organik lebih mudah membusuk dan mencemari lingkungan. Oleh karena itu perlu dilakukan tindakan agar sampah tidak menjadi sumber penyakit terutama penyakit yang bisa menimbulkan kejadian diare.

Tabel 3 menggambarkan, pada kelompok responden yang menderita diare memiliki tempat pembuangan sampah dan memenuhi syarat sebanyak $64,3 \%$, dan responden yang tidak memiliki tempat pembuangan sampah serta tidak memenuhi syarat sebanyak $35,7 \%$.

Berdasarkan hasil analisis statistik, tidak ada hubungan antara tempat pembuangan sampah sementara dengan kejadian diare. Hasil penelitian ini juga sejalan dengan Nugroho (2011) yaitu diperoleh hasil uji statistik yaitu $p$ $=0,705$ dimana $\mathrm{p}>0,05$ berarti Ho gagal ditolak, maka dapat disimpulkan tidak ada hubungan antara tempat pembuangan sampah dengan kejadian diare pada balita.

Sampah merupakan material sisa yang tidakk terpakai lagi dan sampah juga sangat mempengaruhi timbulnya suatu penyakit melalui media perantara vektor. Apabila tempat pembuangan sampah dalam kondisi yang tidak baik maka dapat menyebabkan timbulnya vektor penyakit. Adapun responden perlu mempertahankan dengan adanya tempat pembuangan sampah yang baik dan memenuhi syarat dan lebih bagus lagi ditingkatkan.

\section{d. Saluran Pembuangan Air Limbah}

Sisa air yang dibuang yang berasal dari rumah tangga dan industri pada umumnya mengandung bahan atau zat yang membahayakan, sehingga zat yang terkandung di dalam air limbah terlebih dahulu perlu dibersihkan agar tidak menyebabkan gangguan kesehatan masyarakat dan lingkungan, antara lain limbah sebagai media penyebaran berbagai penyakit terutama kolera, diare, typus, media berkembangbiaknya mikroorganisme patogen dan tempat berkembangbiaknya nyamuk.

Proporsi dari variabel saluran pembuangan air limbah menunjukkan bahwa $56 \%$ tidak ada SPAL, dan $44 \%$ ada SPAL. Hal ini menunjukkan bahwa saluran pembuangan air limbah dalam kondisi yang buruk karena lebih banyak yang tidak ada SPAL. Secara lebih detil dapat dipaparkan bahwa frekuensi kejadian diare pada balita yang tidak ada SPAL dalam saluran pembuangan air limbah sebanyak $76,2 \%$, dan yang telah ada SPAL dalam pembuangan air limbahnya sebanyak $23,8 \%$. Sedangkan yang tidak terkena diare dengan saluran pembuangan air limbah yang tidak ada SPAL sebanyak $11,9 \%$, dan yang telah ada SPAL dalam saluran pembuangan air limbah sebanyak $88,1 \%$. Hasil tersebut disajikan pada tabel 4 .

Berdasarkan analisis statistik, diperoleh nilai $\mathrm{p}=0,000$ dengan $\mathrm{OR}=23,68$. Hal ini menunjukkan bahwa tidak ada SPAL akan mengakibatkan kejadian diare sebesar 23,68 kali dibandingkan dengan yang ada SPAL. Hal ini dibuktikan dengan hasil pengamatan yang dilakukan pada saat penelitian bahwa pembuangan air limbah tidak lancar, saluran air limbah terbuka, tidak kedap air, dan jarak dari sumber air $>10$ meter. Hasil ini sesuai dengan pendapat Notoatmodjo (2003) yang mengemukakan bahwa masalah kesehatan lingkungan utama di negara-negara yang sedang berkembang adalah saluran pembuangan air limbah.

Hasil penelitian ini juga sejalan dengan Bintaro (2010) yaitu diperoleh hasil uji statistik yaitu $\mathrm{p}=0,026$ dimana $\mathrm{p} \leq 0,05$ berarti Ho ditolak dengan $\mathrm{OR}=2,50$, maka dapat disimpulkan ada hubungan antara saluran pembuangan air limbah dengan kejadian diare pada balita. Hal ini dibuktikan dengan hasil pengamatan yang dilakukan pada saat penelitian bahwa pembuangan air limbah tidak lancar, tidak kedap air, jarak sumber air kurang dari 10 meter, saluran air limbah terbuka, dan penampungan air limbah terbuka. Hasil ini sesuai dengan pendapat Notoatmodjo (2003) yang mengemukakan bahwa masalah kesehatan lingkungan utama di negara-negara yang sedang berkembang adalah saluran pembuangan air limbah.

Sebaiknya responden yang tidak memiliki SPAL disarankan untuk membuat SPAL yang sesuai dengan persyaratan seperti kontruksi kedap air, SPAL tertutup, jarak SPAL dengan sumber air $>10$ meter, kondisi SPAL berfungsi dengan baik dan lancar. Sehingga air buangan yang berasal dari rumah tangga tidak mencemari lingkungan dan tidak menimbulkan penyakit diare. 


\section{KESIMPULAN}

Hasil penelitian menyimpulkan teradapat hubungan antara jamban dan saluran pembuangan air limbah dengan kejadian diare pada balita di Kelurahan Way Laga Kecamatan Sukabumi Kota Bandar Lampung. Tidak ada hubungan antara penyediaan air bersih dan tempat pembuangan sampah dengan kejadian diare pada balita di Kelurahan Way Laga Kecamatan Sukabumi Kota Bandar Lampung.

\section{DAFTAR PUSTAKA}

Azwar. 2009. Sanitasi Lingkungan. Pustaka Pelajar. Yogyakarta.

WHO. 2013. Diarrhea Disease [Online]. Tersedia http://www.who.int/mediacentre /factsheets/fs330/en [7 Februari 2017]

Notoatmojo, Soekijo. 2007. Promosi Kesehatan Teori dan Ilmu Perilaku. Rineka Cipta. Jakarta.

Zubir. 2006. Faktor-faktor Resiko Kejadian Diare Akut pada Anak 0-35 Bulan
(BATITA) di Kabupaten Bantul. Sains Kesehatan. Vol 19. No 3. Juli 2006. ISSN $1411-6197: 319-332$

Notoatmojo, Soekijo. 2002. Metodologi

Penelitian Kesehatan. Rineka Cipta. Jakarta.

Ariawan. Iwan. 1998. Besar dan Metode Sampel pada Penelitian Kesehatan. FKMUI. Jakarta.

Bintaro, Bhakti Rochman Tri. 2010. Hubungan Antara Sanitasi Lingkungan Dengan Kejadian Diare Pada Balita Di Kecamatan Jatipuro Kabupaten Karanganyar. Skripsi. FIKUM. Surakarta

Nugroho, Dwi Jayanto, 2011. Hubungan Perilaku Hidup Bersih dan Sehat (PHBS) dengan Kejadian Diare di Kelurahan Tejoagung Kecamatan Metro Timur. Karya Tulis Ilmiah, Poltekkes Tanjungkarang, Lampung. 